\title{
Benign Mediastinal Soft Tissue Neoplasm
}

National Cancer Institute

\section{Source}

National Cancer Institute. Benign Mediastinal Soft Tissue Neoplasm. NCI Thesaurus.

Code C6593.

A non-metastasizing mesenchymal neoplasm that arises from the mediastinum.

Representative examples include lipoma, leiomyoma, and rhabdomyoma. 